\title{
Evaluation of Important Treatment Parameters in Supraphysiological Thermal Therapy of Human Liver Cancer HepG2 Cells
}

\author{
BhaviK ShaH ${ }^{1}$ and SANKha BhOWmick ${ }^{1,2}$ \\ ${ }^{1}$ Department of Mechanical Engineering, University of Massachusetts, Dartmouth, 285 Old Westport Road, North Dartmouth, \\ MA 02747-2300, USA and ${ }^{2}$ Bioengineering and Biotechnology Program, University of Massachusetts, Dartmouth, North \\ Dartmouth, MA, USA
}

(Received 21 December 2005; accepted 21 August 2006; published online: 10 October 2006)

\begin{abstract}
This study was aimed at simulating the effect of various treatment parameters like heating rate $(\mathrm{HR})$, peak temperature (PT) and hold/total treatment time on the viability of human liver cancer HepG2 cells subjected to different thermal therapy conditions. The problem was approached by investigating the injury kinetics obtained using experimentally measured viability of the cells, heated to temperatures of $50-70^{\circ} \mathrm{C}$ for $0-9$ min at $\mathrm{HRs}$ of $100,200,300$ and $525^{\circ} \mathrm{C} \min ^{-1}$. An empirical expression obtained between the activation energy $(E)$ and HR was extended to obtain the $E$ values over a broad range of $\mathrm{HRs}$ from 5 to $600^{\circ} \mathrm{C} \mathrm{min}^{-1}$ that mimic the actual conditions encountered in a typical thermal therapy protocol. Further, the effect of the HR (5-

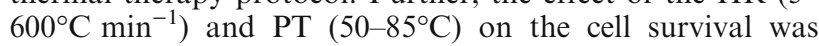
studied over a range of hold times. A significant drop in survival from $90 \%$ to $0 \%$ with the simultaneous increase in HR and PT was observed as the hold time increased from 0 to $5 \mathrm{~min}$. For complete cell death, the hold time increased with the increase in the HR for a given PT, while the total time showed presence of minima for 60,65 and $70^{\circ} \mathrm{C}$ at HRs of 50,100 and $200^{\circ} \mathrm{C} \mathrm{min}{ }^{-1}$, respectively.
\end{abstract}

Keywords-Heating rates, Peak temperatures, Hold time, Total treatment time, Minimal treatment time, Injury kinetics, Arrhenius model, Clinical protocols.

\section{INTRODUCTION}

Primary liver cancer is the fifth most common malignancy in the world, with a global annual incidence of about one million new patients. ${ }^{6}$ In 2004, the American Cancer Society estimated 18,920 new cases of Hepatocellular Carcinoma (HCC) and the estimated deaths were $14,720 .^{1}$ Surgical resection, the gold standard for the treatment of primary liver cancer, shows low success rate $(20-37 \%)$ and a high recur-

Address correspondence to Sankha Bhowmick, Assistant Professor, Bioengineering and Biotechnology Program, University of Massachusetts, Dartmouth, North Dartmouth, MA, USA. Electronic mail: sbhowmick@umassd.edu rence $(50-60 \%)$ rate due to many surgical complications. ${ }^{10,25}$ Liver transplantation is limited because of fewer donors. ${ }^{18}$ Combination treatment methods, using chemotherapy, embolization and chemoembolization have a limited effect even with the newer drugs available and their beneficial effects on the patient survival remain controversial in randomized studies. ${ }^{18,24}$ Use of radiation therapy is limited to alleviating the symptoms such as pain or just to shrink the tissue rather than destroying it. Ablation therapies that use heat to destroy the tumor are gaining increasing attention as an alternative because the treatment procedure is faster, simpler, less painful and cheaper. ${ }^{20}$

There are two known approaches for the application of these ablative procedures: hyperthermia, where the treatment modalities use temperatures ranging from 42 to $50^{\circ} \mathrm{C}$ for periods of $30 \mathrm{~min}$ to few hours. Another approach is thermal therapy, where the destruction of the tumor takes place by the application of heat at temperatures higher than $50^{\circ} \mathrm{C}$ within very short time periods of few minutes to seconds. The tumor is heated using any one of radiofrequency, microwave, laser or high intensity focused ultrasound energy sources. Several clinical trials have been performed to test the efficacy of these thermal ablative therapies in treatment of liver cancer using the abovementioned energy sources. The results have shown survivals of $83-94 \%$ after 1 year, $50 \%$ after 2 years, $33 \%$ after 3 years and $33-40 \%$ after 5 years for hyperthermic radiofrequency ablation in studies conducted on $29-123$ patients. ${ }^{18}$ Survival of $86 \%$ after 1 year in 55 patients has been reported for hyperthermic interstitial laser therapy; ${ }^{12}$ survivals of $73-86 \%$ after 3 years, ${ }^{18} 50 \%$ after 4 years and $48.6 \%$ after 5 years ${ }^{17}$ have been reported for microwave coagulation therapy. In spite of all the above-mentioned clinical trials, no data exists showing the effect of thermal therapy on the survival of liver cancer cells. Effect of hyperthermic temperatures on human liver cancer cell 
lines has also been investigated in few in vitro studies. Callari et al. ${ }^{7}$ used HTC hepatoma cells to study the action of retinol on viable cell recovery after in vitro hyperthermia at temperatures between $42^{\circ} \mathrm{C}$ and $44^{\circ} \mathrm{C}$ for $1 \mathrm{~h}$. Hasumura et al. ${ }^{13}$ studied the effect of TNF along with hyperthermia on $\mathrm{JHH}-4, \mathrm{JHH}-5$ and $\mathrm{JHH}-7$ human hepatoma cells between temperatures of $41.4^{\circ} \mathrm{C}$ and $42.5^{\circ} \mathrm{C}$. However, none of the studies demonstrated the effect of temperatures above $50^{\circ} \mathrm{C}$ any liver cancer cell lines.

Since in thermal therapy, the injury accumulates at very high temperatures within a short period of time, knowledge of the injury kinetics is very useful for predicting the cell/tumor damage ${ }^{15}$ for these thermal histories. Several thermal therapy studies have been performed to obtain the injury kinetics in different cell lines. Landry et al. ${ }^{19}$ heated HeLa cells up to $55^{\circ} \mathrm{C}$ using water bath, with thermal equilibrium time of $1 \mathrm{~min}$ for $55^{\circ} \mathrm{C}$. To reduce this equilibrium time Borrelli et al. ${ }^{5}$ heated cells to $57^{\circ} \mathrm{C}$ on $0.025-\mathrm{mm}$ thick mylar pieces. Cell injury kinetics was obtained by measuring the cell survival using clonogenic assay in both the studies. In addition, studies on T24 human bladder carcinoma, ${ }^{22}$ skeletal muscle, ${ }^{11} \mathrm{SN} 12$ renal cell carcinoma ${ }^{15}$ and Dunning AT-1 prostate cancer cells ${ }^{4}$ in the temperature range of $40-70^{\circ} \mathrm{C}$ obtained cell injury kinetics using dye uptake assays and thus showed that dye uptake assay is a reasonable conservative estimate of the cell survival. Also, two recent in vitro studies in human benign prostatic hyperplasia tissue and rodent prostate cancer tissue showed that the cell injury kinetics measured by membrane integrity vital dye assay and histology assays are very similar. ${ }^{2,3}$ Therefore, a key observation from the above studies is that vital dye uptake assay can be used as an alternate and reliable conservative maker as it provides rapidity, automation and better control. ${ }^{15}$

A key difference of high temperature-short time thermal therapy protocols from the traditional hyperthermia protocols is the significant injury accumulation during the non-isothermal portion of the thermal history (heating up/cooling down period). Therefore, injury accumulation tends to be a complex function of hold time as well ramp up and cooling time. Hence, accurate prediction of the cell injury kinetics requires the knowledge of heating/ cooling rates in addition to peak temperatures (PTs) and hold/total time. This model also better represents the thermo-clinical applications because the rate at which the PTs are achieved at different locations inside the tumor vary with the applicator location and plays a paramount role in determining the amount of injury accumulated. The knowledge of the injury accumulated in reaching a PT or the PT required to obtain a desired injury under different heating rates (HRs) are some of the very important parameters in designing better and optimal clinical protocols.

This study was used to investigate experimentally and through simulations the parameters affecting thermal therapy of primary human liver cancer HepG2 cells between $50^{\circ} \mathrm{C}$ and $70^{\circ} \mathrm{C}$ using Ethd- 1 uptake cell membrane integrity assay. The cells were thermally challenged on a programmable heating stage which can control and record the entire thermal history profile, allowing us to recreate typical thermal therapy protocols. Cell membrane integrity dye uptake (Ethd-1) was used as an irreversible injury marker. The first-order Arrhenius rate model was used to extract the kinetic parameters activation energy, $E\left(\mathrm{~kJ} \mathrm{~mol}^{-1}\right)$ and frequency factor $A\left(\mathrm{~s}^{-1}\right) .{ }^{16}$ The survival data was fitted into the Arrhenius model for various HRs and the $E$ and $A$ values were predicted by minimizing the least square between the model predictions and the experimental data for suspended and attached cells. Based on the predicted $E$ values, a relationship between the $E$ and HR was obtained experimentally and was further used to simulate the survival map for different hold periods by varying the target PT and the HR. Finally, the hold time and the total injury time necessary for complete cell death (Survival $\leq 0.001 \%$ ) was predicted for target

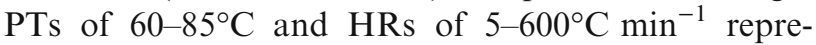
senting the typical transient thermo-clinical protocol.

\section{MATERIALS AND METHODS}

\section{HEPG2 Cell Culture and Sample Preparation}

Human liver cancer Hepg2 cells (ATCC, VA) were propagated in MEM cell culture media with $10 \%$ Fetal Bovine Serum (Hyclone, UT) and 1\% penicillin/streptomycin (Invitrogen, CA). They were then incubated in $10 \% \mathrm{CO}_{2}$ and $95 \%$ humidified air at $37^{\circ} \mathrm{C}$ in $75-\mathrm{cm}^{2} \mathrm{~T}$ flasks. The cells were trypsinized with Trypsin-EDTA (ATCC, VA) for 5-10 min, centrifuged at $1200 \mathrm{rpm}$ for $5 \mathrm{~min}$ and re-suspended in the media to an appropriate concentration. Suspended cell samples were prepared by placing $3 \mu \mathrm{l}$ of cell suspension onto the center of the $12-\mathrm{mm}$ diameter coverglass, covering it with another coverglass to prevent evaporation during heating. For attached cell studies, cell suspension was scattered over about 18-20, 12-mm cover glasses lying in a $110-\mathrm{mm}$ diameter Petri dish. Overnight attachment of the cells on top of the coverglass was allowed in the incubator and then the cell sample was prepared in the same way as the suspended sample. 


\section{Heating Stage}

Attached and suspended cell samples were heated on a programmable heating stage, at different HRs. Figure 1 shows the setup diagram of the heating stage and the feedback control used. Cement T-type thermocouple (Omega Engg Inc., CT) was used for temperature detection, which is interfaced with a data acquisition board (DAB) (Keithly Inc., Cleveland, $\mathrm{OH})$ connected to the computer port. The interface between the user and the DAB is through a Visual Basic code that calculates the output voltage based on the set point and instantaneous temperature and controls it based on proportional and derivative constants used in the feedback loop. Table 1 shows the combinations of proportionality $\left(k_{\mathrm{p}}\right)$ and derivative $\left(k_{\mathrm{d}}\right)$ constants used in the feedback loop to achieve different HRs $\left(100,200,300\right.$ and $\left.525^{\circ} \mathrm{C} \mathrm{min}^{-1}\right)$. An OPAMP (Analog Devices Inc, MA) circuit is used to amplify the feedback voltage signal from the DAB and heat the stage. The stage was calibrated using fixed temperature tempi labels and sticks (MSC Industrial Supply Co., $\mathrm{NY}$ ) to an accuracy of $\pm 0.3^{\circ} \mathrm{C}$ for all PTs at each HR used in the study.

\section{Heating Studies and Ethd-1 Dye Uptake Assay}

Suspended and attached HepG2 cell samples were heated to different time-temperature histories. Iso-
Table 1. Values of proportionality $\left(k_{\mathrm{p}}\right)$ and derivative $\left(k_{\mathrm{d}}\right)$ constants for different HRs to obtain desired PTs.

\begin{tabular}{lcll}
\hline $\mathrm{HR}\left({ }^{\circ} \mathrm{C} \mathrm{min}^{-1}\right)$ & $\mathrm{PT}\left({ }^{\circ} \mathrm{C}\right)$ & \multicolumn{1}{c}{$k_{\mathrm{p}}$} & \multicolumn{1}{c}{$k_{\mathrm{d}}$} \\
\hline \multirow{2}{*}{100} & 60 & 0.0155 & 0.0925 \\
& 65 & 0.0155 & 0.0925 \\
& 70 & 0.0155 & 0.0925 \\
& 60 & 0.035 & 0.108 \\
& 60 & 0.035 & 0.108 \\
300 & 70 & 0.035 & 0.121 \\
& 60 & 0.085 & 0.255 \\
& 65 & 0.085 & 0.255 \\
& 70 & 0.0903 & 0.275 \\
\hline
\end{tabular}

thermal heating was carried out for suspended and attached cells at temperatures between $50^{\circ} \mathrm{C}$ and $70^{\circ} \mathrm{C}$ for $0.5-9 \mathrm{~min}$. The cell sample was placed on the center of the heating stage after the PT was reached. The time for each cell sample to equilibrate to any given PT was experimentally calculated to be $\sim 5 \mathrm{~s}$ and was added to the hold time during heating. HRs of 100, 200 and $300^{\circ} \mathrm{C} \mathrm{min}^{-1}$ were employed for heating attached cells non-isothermally between temperatures of $60^{\circ} \mathrm{C}$ and $70^{\circ} \mathrm{C}$ for a hold time of $0-3 \mathrm{~min}$ using the entire temperature-time history, which includes the rise, hold and the cooling period. The HRs were assumed to be constant for the entire thermal history and were obtained by taking a tangent to the exponential curve of the temperature rise. Therefore, the cell sample was placed on the center of the heating stage before starting

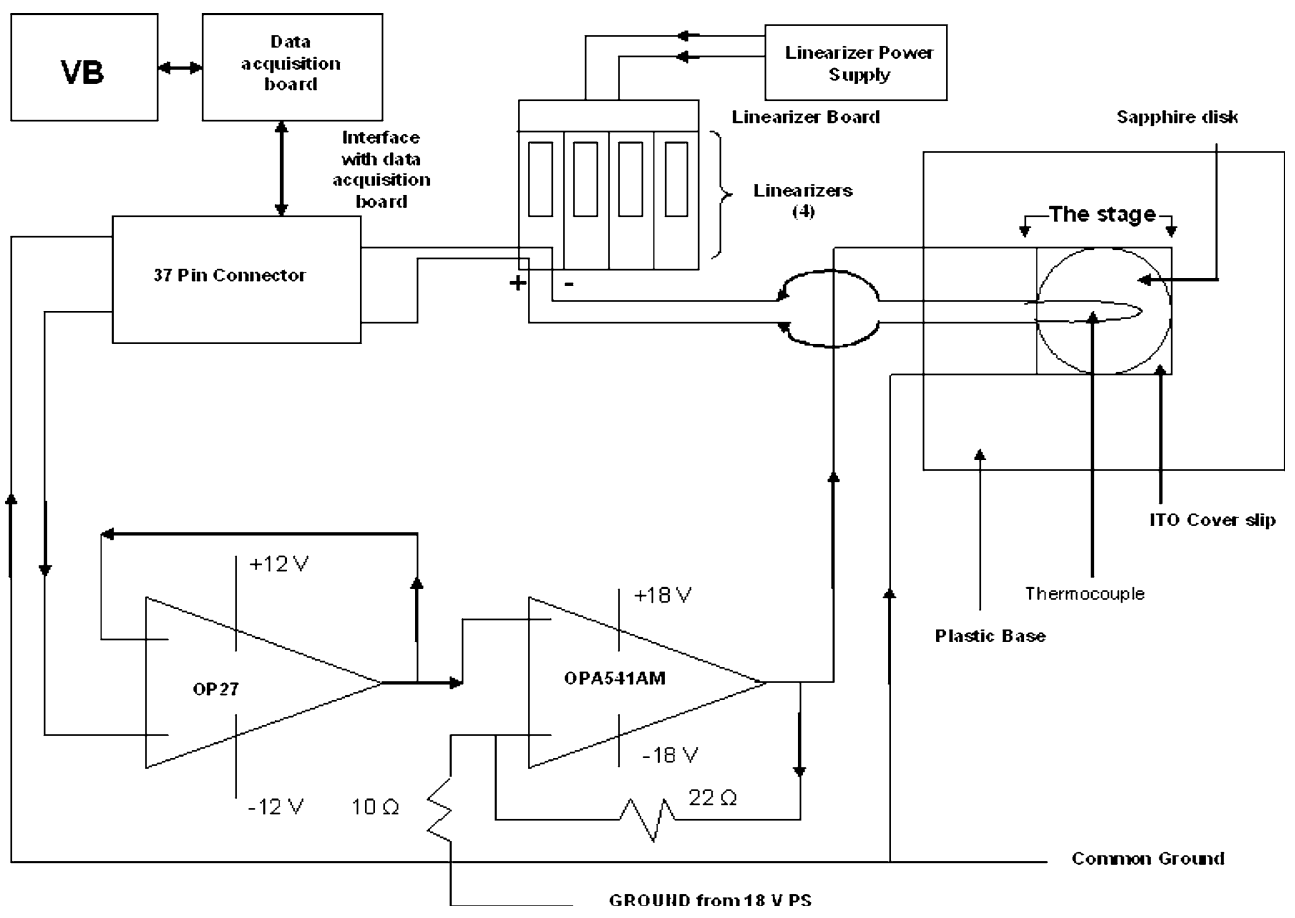

FIGURE 1. Block diagram of the amplifying OPAMP circuit and feedback control of the heating stage. The OPAMP circuit amplifies the voltage signal from the data acquisition board to heat the stage, while the feedback control system, through the VB code, controls the amount of voltage based on the instantaneous temperature of the stage. 
the heating cycle. The cooling time for each sample from a given PT was calculated based on the experimentally measured cooling rate of $100^{\circ} \mathrm{C} \mathrm{min}^{-1}$.

Cellular injury post heating for isothermal and nonisothermal studies was quantified using Ethd-1 (SigmaAldrich, MO) vital dye assay by counting the number of cells stained with Ethd-1 dye (dead only) and the total number of the cells stained with Hoechst (SigmaAldrich). Thermally treated cell samples were placed in a $50 \mu \mathrm{l}$ drop of $2.5 \mu \mathrm{M}$ Ethd- 1 and $10 \mu \mathrm{M}$ Hoechst dye solution in a $35-\mathrm{mm}$ Petri dish and incubated for $3 \mathrm{~h}$. The incubation time of $3 \mathrm{~h}$ was based on the experiments conducted after 1, 2 and $3 \mathrm{~h}$ of incubation (data not included), which confirmed that membrane damage equilibrates within this period and a significant amount of media is pulled between the cover glasses to stain the cells. Control samples underwent the same procedure without heating. After $3 \mathrm{~h}$, the dead and the total number of cells were counted with a fluorescent microscope (Nikon Eclipse TS 100, Tokyo) using a $20 \times$ objective. Multiple fields with at least $150-300$ cells were counted for each run.

\section{Normalized Cell Survival}

For all the cell samples, the normalized cell survival $\left(S_{\mathrm{e}}\right)$ was calculated as follows:

$$
S_{\mathrm{e}}=\left[\left(N_{\mathrm{H}, \mathrm{t}}-N_{\mathrm{E}, \mathrm{t}}\right) / N_{\mathrm{H}, \mathrm{t}}\right] /\left[\left(N_{\mathrm{H}, \mathrm{c}}-N_{\mathrm{E}, \mathrm{c}}\right) / N_{\mathrm{H}, \mathrm{c}}\right]
$$

$N_{\mathrm{H}}$ and $N_{\mathrm{E}}$ are the number of total and dead cells stained with Hoechst and Ethd-1 respectively; subscripts ' $t$ ' and ' $c$ ' represent thermally treated and control cells, respectively. The calculated cell survival was based on three separate experiments, with two runs for every data point in each experiment.

\section{The Cell Injury Model}

Thermally induced cellular injury was considered as a first-order irreversible process as shown below and as used in many previous heating studies;

$$
V \stackrel{k}{\rightarrow} I
$$

where $V$ represents the viable state of a cell, $I$ represents the injured state of a cell and $k$ is the cell injury rate. The predicted cell viability $\left(S_{\mathrm{c}}\right)$ was calculated using the following equation:

$$
S_{\mathrm{c}}=\exp \left(-\int_{0}^{\delta} k d t\right)
$$

$\delta$ is the total treatment time (s).
The Arrhenius model ${ }^{16}$ was adopted in this study as it has been extensively used in previous studies to obtain the cell injury kinetics ${ }^{14,21}$ as shown below;

$$
k=A \exp \left(\frac{-E}{R T}\right)
$$

$A$ is frequency factor $\left(s^{-1}\right), E$ is activation energy $\left(\mathrm{J} \mathrm{mol}^{-1}\right)$ and $R$ is the universal gas constant $\left(8.314 \mathrm{~J} \mathrm{~mol}^{-1} \mathrm{~K}^{-1}\right) . A$ and $E$ are related by an empirical formula, obtained by compiling the injury kinetics of various proteins, cells and tissues. ${ }^{15}$

$$
\ln (A)=0.38 \mathrm{E}-9.36
$$

\section{Determination of Arrhenius Model Parameters}

The kinetic parameters $E$ and $A$ were determined by fitting Eqs. (4) and (5) in Eq. (1) as obtained by $\mathrm{He}$ and Bischof $^{15}$ They were further refined using a simple optimization subroutine to minimize the root mean square error between the experimental data and model prediction.

$$
f(\mathrm{X})=\left[\frac{1}{N} \sum_{i=1}^{n}\left(S_{\mathrm{e}, i}(\mathrm{X})-S_{\mathrm{c}, i}(\mathrm{X})\right)^{2}\right]^{0.5}
$$

$N$ is the total number of data points, vector ' $\mathrm{X}$ ' contains variables $E$ and $A$. $S_{\mathrm{e}, \mathrm{i}}$ and $S_{\mathrm{c}, \mathrm{i}}$ represent the $i$ th measured data point and model fit, respectively. The goodness of the fit $\left(R^{2}\right)$ is calculated as follows:

$$
R^{2}=1-\frac{\sum\left(\left(S_{\mathrm{e}, i}(\mathrm{X})-S_{\mathrm{c}, i}(\mathrm{X})\right)^{2}\right)}{\sum\left(\left(S_{\mathrm{e}, i}(\mathrm{X})-S_{\mathrm{av}}\right)^{2}\right)}
$$

$S_{\text {av }}$ is the measured average survival from the Etdh-1 studies.

\section{RESULTS}

The results were generated by counting the number of total and dead cells from the micrographs of the cell samples as shown in Fig. 2 and using Eq. (1) to calculate the normalized cell survival for each sample. Figure $2 \mathrm{a}, \mathrm{b}$ represent the control sample, where the number of dead cells, stained with Ethd-1 (red) dye, is very less compared to the total number of cells, stained with Hoechst (blue) dye and the cell survival is higher than 0.96 . The cell survival decreases slightly as the number of dead cells compared to the total number of cells increases for the cell sample heated at $50^{\circ} \mathrm{C}$ for 9 min, as shown in Fig. 2c, d. The survival drops dramatically with a sharp increase in the number of 

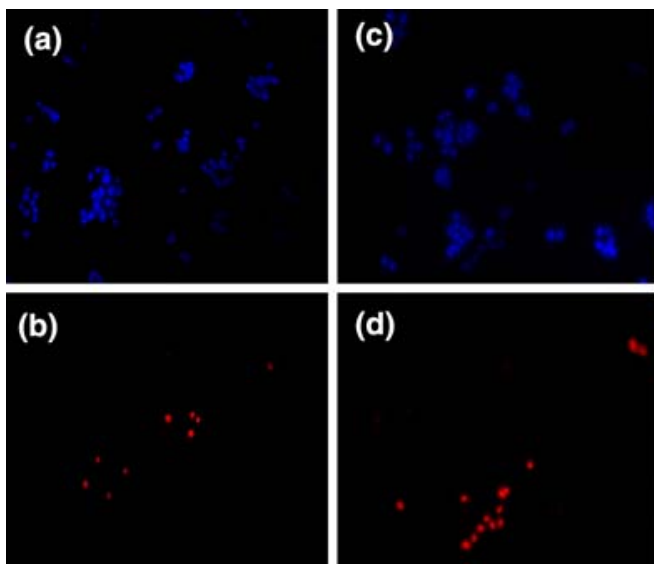
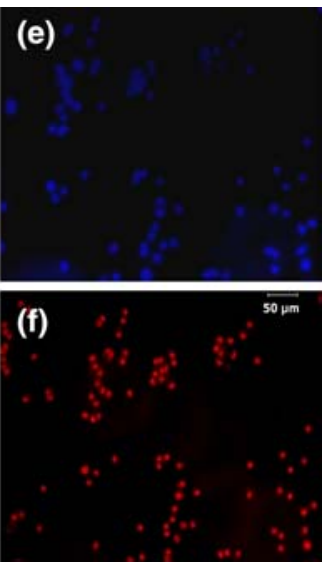

FIGURE 2. Micrographs showing cell samples stained with Hoechst (Blue-all cells) and Ethd-1 (Red-dead cells only). (a and b) control samples without heating; (c and d) - samples heated at $50^{\circ} \mathrm{C}$ for $9 \mathrm{~min}$; (e and f) - samples heated at $70^{\circ} \mathrm{C}$ for $1 \mathrm{~min}$.

dead cells compared to total cells at $70^{\circ} \mathrm{C}$ as seen in Fig. 2e, f.

\section{Isothermal Heating Studies}

The isothermal heating studies were used to understand the effect of different temperature-time histories on the viability of attached and suspended HepG2 cells and to quantify the cellular injury associated with these histories. All the cell samples reached the PTs in $\sim 5 \mathrm{~s}$ at an approximate $\mathrm{HR}$ of $525^{\circ} \mathrm{C} \mathrm{min}{ }^{-1}$ resulting in a negligible difference between the hold time and the total time of the treatment. Thus heating at the rate of $525^{\circ} \mathrm{C} \mathrm{min}{ }^{-1}$ was referred as isothermal heating.

The data in Fig. 3a, b represents the mean and the standard error for measured cell viability of attached and suspended HepG2 cells respectively using Ethd-1 dye uptake assay. Both the figures show that for a given PT, the survival drops with the increase in the hold time. At $50^{\circ} \mathrm{C}$, the survival drops from 0.84 to 0.43 for suspended cells and from 0.89 to 0.62 for attached cells, as the hold time increases from 2 to $9 \mathrm{~min}$. Similar trend was observed for heating at all the PTs. The figures also show that for a given hold time, the cell survival drops with the increase in the PT for suspended cells. For a hold time of $2 \mathrm{~min}$, the cell survival drops from 0.84 to 0.52 and from 0.52 to 0.29 as the PT increases from $50^{\circ} \mathrm{C}$ to $55^{\circ} \mathrm{C}$ and from $55^{\circ} \mathrm{C}$ to $60^{\circ} \mathrm{C}$, respectively. For a hold time of $1 \mathrm{~min}$, the cell survival drops from 0.45 to 0.1 and from 0.1 to 0.003 as the PT increases for $50^{\circ} \mathrm{C}$ to $55^{\circ} \mathrm{C}$ and from $55^{\circ} \mathrm{C}$ to $60^{\circ} \mathrm{C}$, respectively. The same trend is also seen for the attached cells but with slightly higher survival.

The figures also show the effect of PTs on the slope of the survival curve. The drop in the survival with the increase in the hold time is slow at low PTs. The survival curve gets steeper as the PT increases. When heated at $50^{\circ} \mathrm{C}$ for up to $9 \mathrm{~min}$, the cell survival is still higher than 0.43 for both suspended and attached cells. This trend changes for $55^{\circ} \mathrm{C}$, where the cell survival drops to 0.03 after only 6 min of heating. This trend magnifies sharply as the PTs increases to 60,65 and $70^{\circ} \mathrm{C}$. For suspended cells, the survival at $60^{\circ} \mathrm{C}$ varies from 0.58 to almost zero survival as the hold time increases from 0.5 to $3 \mathrm{~min}$. The survival dropped from 0.2 to 0.003 for an increase in the hold time from $15 \mathrm{~s}$ to a min at $70^{\circ} \mathrm{C}$. The attached cells also showed a similar trend with slightly higher survival than the suspended cells for all the data points.

The student $t$-test assuming unequal variance was used to observe the statistical significance between the experimentally measured cell viability of suspended and attached HepG2 cells as shown in Fig. 3c. With $p=0.05$ as the criterion, no significant difference in the cell viability was observed for most of the data points. The data points that were significantly different $(p<0.05)$ are $50^{\circ} \mathrm{C}-5 \mathrm{~min}, 50^{\circ} \mathrm{C}-9 \mathrm{~min}, 60^{\circ} \mathrm{C}-$ $3 \mathrm{~min}$ and $70^{\circ} \mathrm{C}-1 \mathrm{~min}$. This difference for data points of $60^{\circ} \mathrm{C}-3 \mathrm{~min}$ and $70^{\circ} \mathrm{C}-1 \mathrm{~min}$ can be neglected as the experimentally calculated cell viability in suspended and attached HepG2 for both these thermal insults is of the order $10^{-3}$. The $p$-value of 0.088 for $60^{\circ} \mathrm{C}-2$ min data point suggests the difference in the cell viability is not significant, but is still different. As no significant difference between the survival of suspended and attached HepG2 cells was observed for most of the time-temperature histories and since attached cells better describe the arrangement of the cells in a tissue, only attached cells were used for further non-isothermal studies. 
hold time ( $\min )$
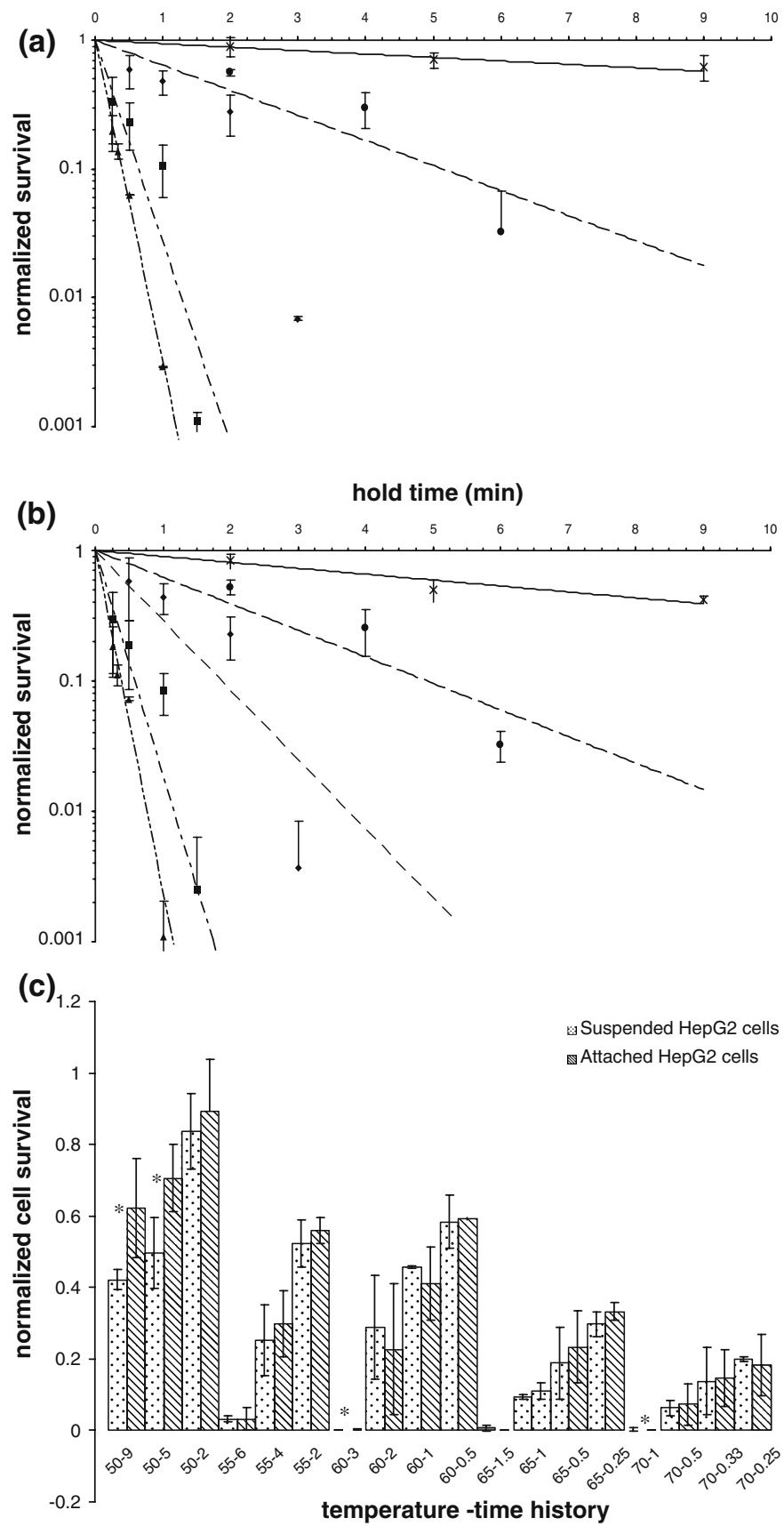

FIGURE 3. (a) Plot of experimentally measured and predicted survival of attached cells heated isothermally versus hold time in minutes for single cell heating at PTs of $50,55,60,65$ and $70^{\circ} \mathrm{C}$. Cross $(\times)$, filled circles $(\bullet)$, filled diamonds $(\bullet)$, filled squares $(\bullet)$ and filled triangles $(\Delta)$ represents heating of samples at $50,55,60,65$ and $70^{\circ} \mathrm{C}$, respectively. The lines represent the exponential fit through all the data points based on the predicted $E$ and $A$ values. (b) Plot of experimentally measured and predicted survival of suspended cells heated isothermally versus hold time in minutes for single cell heating at PTs of $50,55,60,65$ and $70^{\circ} \mathrm{C}$. Cross $(\times)$, filled circles $(\bullet)$, filled diamonds $(\bullet)$, filled squares $(\square)$ and filled triangles $(\Delta)$ represents heating of samples at $50,55,60,65$ and $70^{\circ} \mathrm{C}$ respectively. The lines represent the exponential fit through all the data points based on the predicted $E$ and $A$ values. (c) Direct comparison between suspended and attached HePG2 cell viability, using student $t$-test assuming unequal variance. Each data point is an average of three separate runs using two different cell samples for each run. The error bar in the figure represents the standard error of the mean. Data points marked with asterisks indicate the data points where viability of suspended and attached cells is significantly different. 
Table 2. Activation energy $E\left(\mathrm{~kJ} \mathrm{~mol}^{-1}\right)$ and frequency factor $A\left(\mathrm{~s}^{-1}\right)$ using all the data point for different HRs.

\begin{tabular}{lcc}
\hline $\mathrm{HR}\left({ }^{\circ} \mathrm{C} \mathrm{min}^{-1}\right)$ & $\begin{array}{c}\text { Activation } \\
\text { energy } E \\
\left(\mathrm{~kJ} \mathrm{~mol}^{-1}\right)\end{array}$ & $\begin{array}{c}\text { Frequency } \\
\text { factor } A\left(\mathrm{~s}^{-1}\right)\end{array}$ \\
\hline 100 & 272.4 & $7.757 \times 10^{40}$ \\
200 & 262.02 & $1.502 \times 10^{39}$ \\
300 & 257.38 & $2.576 \times 10^{38}$ \\
525 (Isothermal - Attached) & 248.64 & $5.396 \times 10^{36}$ \\
525 (Isothermal - Suspended) & 229.46 & $3.495 \times 10^{31}$ \\
\hline
\end{tabular}

The parameters of cell injury, $E$ and $A$, were obtained by fitting the Arrhenius rate model into the survival data. This was done by minimizing the function in Eq. (6) using Eqs. (3) and (4). The predicted $E$ and $A$ values for suspended and attached cells for isothermal heating are shown in Table 2. The $E$ and $A$ values obtained for suspended cells are $229.46\left(\mathrm{~kJ} \mathrm{~mol}^{-1}\right)$ and $3.495 \times 10^{31}$ $\left(\mathrm{s}^{-1}\right)$ and those for attached cells are $248.64\left(\mathrm{~kJ} \mathrm{~mol}^{-1}\right)$ and $5.396 \times 10^{36}\left(\mathrm{~s}^{-1}\right)$, respectively. The predicted survival based on the predicted $E$ and $A$ values for attached and suspended cells is shown by the solid lines in Fig. 3a, b, respectively. The goodness of the fit

(a) hold time ( $\mathrm{min})$

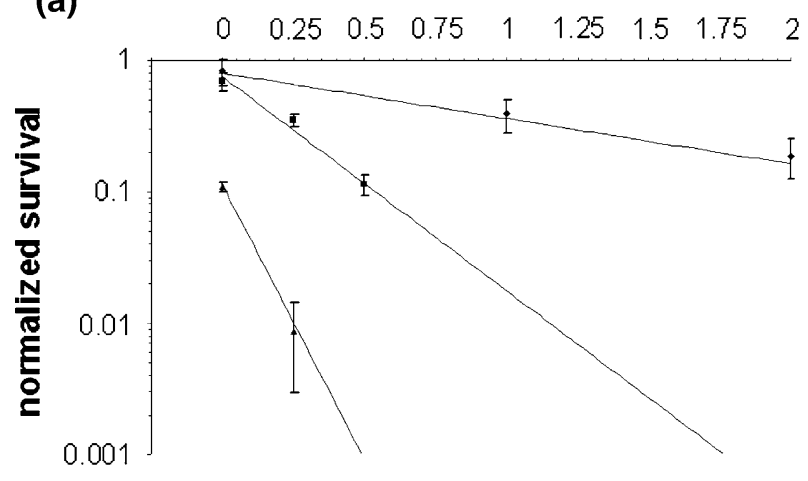

hold time (min)

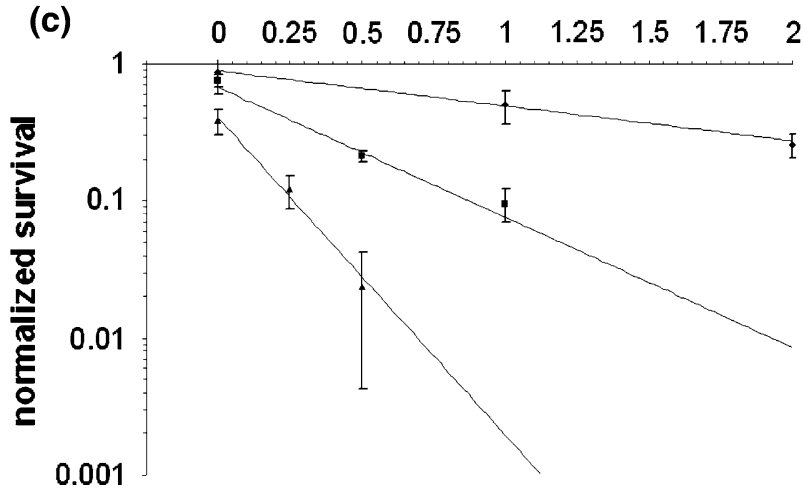

between the predicted and experimentally measured values, obtained using Eq. (7) for suspended and attached cells, is 0.86 and 0.84 , respectively.

\section{Non-Isothermal Heating Studies}

The study focused next on the investigation of the effect of different HRs on the cell viability of attached HepG2 cells and extraction of kinetic parameters of the cellular injury associated with each HR. The HRs of 100,200 and $300^{\circ} \mathrm{C} \mathrm{min}^{-1}$ were employed in this study, as they all showed a considerable difference in the rise-time at all the PTs. The total injury time (rise, hold and cooling time) was taken into account to quantify the thermal injury for all the HRs.

The data in Fig. 4a-c represents the mean and the standard error of the measured cell viability using Ethd-1 dye uptake assay for attached HepG2 cells at HRs of 100,200 and $300^{\circ} \mathrm{C} \mathrm{min}^{-1}$, respectively. All the figures show that, for a given HR, the cell survival drops with the increase in the hold time and the PT, similar to that observed in isothermal heating. At the HR of $100 \mathrm{C} \mathrm{min}^{-1}$, the survival drops from 0.82 for

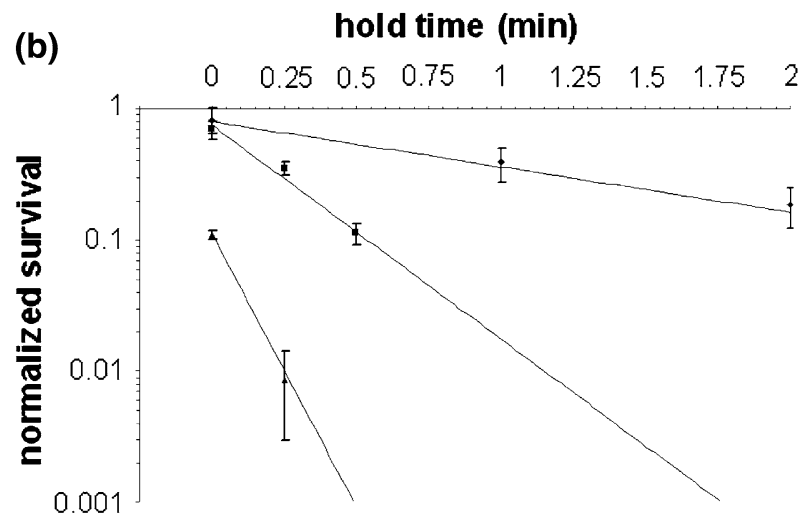

FIGURE 4. Plot of experimentally measured and predicted survival of attached cells heated at various heating rates versus time in minutes for single cell heating at temperature $60,65 \& 70^{\circ} \mathrm{C}$. (a) $100^{\circ} \mathrm{C} \mathrm{min} \mathrm{m}^{-1}$. (b) $200^{\circ} \mathrm{C} \mathrm{min}-1$. (c) $300^{\circ} \mathrm{C} \mathrm{min}$. Filled diamonds ( $\bullet$ ), filled squares $(\square)$ and filled triangles $(\Delta)$ represents heating of samples at 60,65 and $70^{\circ} \mathrm{C}$ respectively. The lines represent the exponential fit through all the data points based on the predicted $E$ and $A$ values. 
no hold time to 0.18 for a hold time of 2 min for a PT of $60^{\circ} \mathrm{C}$. This trend remains the same for the PTs of $65^{\circ} \mathrm{C}$ and $70^{\circ} \mathrm{C}$ and for all the HRs. The survival drops from 0.82 at $60^{\circ} \mathrm{C}$ to 0.69 at $65^{\circ} \mathrm{C}$ and further to

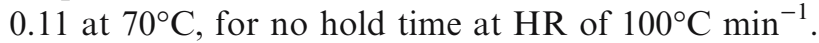
This trend continues for all the HRs and at all the hold times. The figures also illustrates that for any given PT and for a given hold time, the cell survival increases with the increase in the $\mathrm{HR}$. At $60^{\circ} \mathrm{C}$ for no hold time, the survival increases from 0.82 at $100^{\circ} \mathrm{C} \mathrm{min}{ }^{-1}$ to 0.85 at $200^{\circ} \mathrm{C} \mathrm{min}^{-1}$ and further to 0.88 at $300^{\circ} \mathrm{C} \mathrm{min}{ }^{-1}$. At $65^{\circ} \mathrm{C}$ for a hold time of $0.5 \mathrm{~min}$, the survival increases from 0.15 at $100^{\circ} \mathrm{C} \mathrm{min}^{-1}$ to 0.19 at $200^{\circ} \mathrm{C} \mathrm{min}^{-1}$ and then to 0.22 at $300^{\circ} \mathrm{C} \mathrm{min}{ }^{-1}$. This trend also continues for $70^{\circ} \mathrm{C}$ for any given hold time.

A trend was observed in the Arrhenius parameters obtained from the non-isothermal heating studies as the $E$, and the corresponding $A$ value, decreased with the increase in the HR. Table 2 shows the predicted $E$ and $A$ values for HRs of 100,200 and $300^{\circ} \mathrm{C} \mathrm{min}^{-1}$. The activation energy decreases from $272.40 \mathrm{~kJ} \mathrm{~mol}^{-1}$ at $100^{\circ} \mathrm{C} \mathrm{min}^{-1}$ to $262.02 \mathrm{~kJ} \mathrm{~mol}^{-1}$ at $200^{\circ} \mathrm{C} \mathrm{min}^{-1}$ and then to $257.38 \mathrm{~kJ} \mathrm{~mol}^{-1}$ at $300^{\circ} \mathrm{C} \mathrm{min}^{-1}$. The solid lines in the Fig. $5 \mathrm{a}-\mathrm{c}$ represent the predicted cell survival based on above values respectively. The goodness of fit between the predicted and measured cell survival for all data points obtained using Eq. (7) is 0.97 for all the HRs used in this study.

\section{Relation Between Activation Energy and HRs}

The following relation was obtained by fitting a polynomial trend line through the data in Table 2 that includes the isothermal heating at $525^{\circ} \mathrm{C} \mathrm{min}{ }^{-1}$;

$$
E=0.0001(H R)^{2}-0.1173(H R)+282.67
$$

$E$ represents the activation energy and HR represents the HR. The above equation was then used to obtain the values of activation energy over a range of HRs from 5 to $600^{\circ} \mathrm{C} \mathrm{min}^{-1}$ in order to simulate the effects of various parameters on the cell survival. The values of the activation energy shows a small decrease from 282.09 to $248.29 \mathrm{~kJ} \mathrm{~mol}^{-1}$ over a large increase in the $\mathrm{HR}$ increased from 5 to $600^{\circ} \mathrm{C} \mathrm{min}^{-1}$.

\section{Effects of PTs, HRs and Hold Time on the Cell Survival}

Based on the $E$ and $A$ values obtained at HRs of 5$600^{\circ} \mathrm{C} \min ^{-1}$ using the $E-\mathrm{HR}$ relation, the cell survival was predicted at different hold times for PTs between $50^{\circ} \mathrm{C}$ and $85^{\circ} \mathrm{C}$. The combined effect of the increase in the hold time and PT on the cell survival is shown in the Fig. $5 \mathrm{a}-\mathrm{d}$ for all the HRs mentioned above.
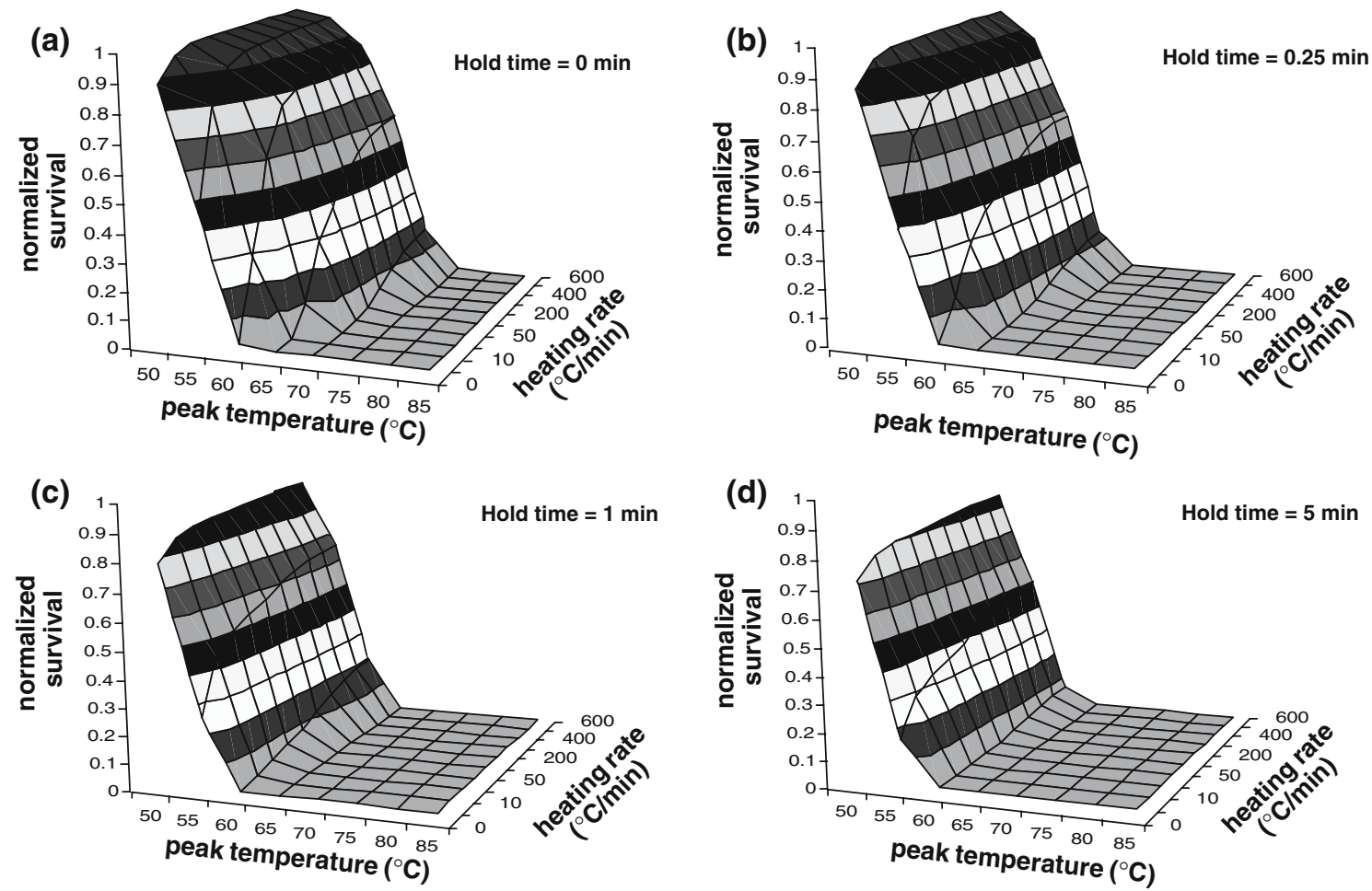

FIGURE 5. Plot of the normalized survival of attached cells for various hold times at different peak temperatures and heating rates based on the predicted $E$ and $A$ values. (a) $0 \mathrm{~min}$. (b) $0.25 \mathrm{~min}$. (c) $1 \mathrm{~min}$. (d) $5 \mathrm{~min}$. 
For a given hold time and HR, the cell survival drops consistently with the increase in the PT. For a $\mathrm{HR}$ of $20^{\circ} \mathrm{C} \mathrm{min}^{-1}$, the cell survival drops from 0.98 at $50^{\circ} \mathrm{C}$ to 0.091 at $65^{\circ} \mathrm{C}$ and then to no cell survival at temperature above $75^{\circ} \mathrm{C}$, when the hold time is $0 \mathrm{~min}$. The trend remains the same for any HR and hold time combination. The drop in the cell survival for any hold time is lower when the PTs are $55^{\circ} \mathrm{C}$ and less. The survival drops slightly from 0.96 at $50^{\circ} \mathrm{C}$ to 0.84 at $55^{\circ} \mathrm{C}$ for heating at $200^{\circ} \mathrm{C} \mathrm{min}{ }^{-1}$ for a hold time of $1 \mathrm{~min}$. This drop is higher, from 0.84 to 0.48 , when the temperature increases to $60^{\circ} \mathrm{C}$. This trend is magnified with the increase in the PT to $65^{\circ} \mathrm{C}$ where the survival drops to 0.05 and to almost complete cell destruction for a further $5^{\circ} \mathrm{C}$ rise in the PT. At any given hold time and PT, the cell survival increases with the increase in the HR. The survival increased from 0.006 to 0.56 at $60^{\circ} \mathrm{C}$ for a hold time of $1 \mathrm{~min}$ and from 0 to 0.002 for a hold time of $3 \mathrm{~min}$ at $65^{\circ} \mathrm{C}$ as the $\mathrm{HR}$ increased from 5 to $600^{\circ} \mathrm{C} \mathrm{min}^{-1}$.

For a given PT and a HR, the cell survival drops with the increase in the hold time. At $60^{\circ} \mathrm{C}$ and $50^{\circ} \mathrm{C} \mathrm{m^{-1 }}$ the cell survival drops from 0.76 to 0.008 when the hold time increases from 0 to $5 \mathrm{~min}$. For the same increase in the hold time, the survival drops from 0.12 to zero at $70^{\circ} \mathrm{C}$ and $400^{\circ} \mathrm{C} \mathrm{min}{ }^{-1}$. For any hold time, almost complete cell destruction takes place at all the HRs when the PTs are $75^{\circ} \mathrm{C}$ and above. For HRs of $50^{\circ} \mathrm{C} \mathrm{min}{ }^{-1}$ and lower, the PT to acquire almost complete cell death decreases with the increase in hold time. For zero hold time, $70^{\circ} \mathrm{C}$ shows a survival of 0.004 and less for HRs of $50^{\circ} \mathrm{C} \mathrm{min}^{-1}$ and less. When the hold time is $1 \mathrm{~min}$, complete cell death is observed at $65^{\circ} \mathrm{C}$ for all the $\mathrm{HRs}$ below $50^{\circ} \mathrm{C} \mathrm{min}{ }^{-1}$ and at $60^{\circ} \mathrm{C}$ for HR of $5^{\circ} \mathrm{C} \mathrm{min}^{-1}$. The survival at $55^{\circ} \mathrm{C}$ decreases considerably with hold time at these low HRs but is still significantly high $(>10 \%)$, while the survival at $50^{\circ} \mathrm{C}$ shows a very less drop. For a $\mathrm{HR}$ of $10^{\circ} \mathrm{C} \mathrm{min}^{-1}$, the survival at $55^{\circ} \mathrm{C}$ drops from 0.79 to 0.28 with the increase in the hold time from 0 to $5 \mathrm{~min}$. At $50^{\circ} \mathrm{C}$, this drop is from 0.96 to 0.79 . This trend is depicted in Fig. 5a-d as the drop in the slope of the vertical portion with the increase in the hold time.

\section{Hold and Total Injury Time for Complete Cell Destruction}

The relationship between activation energies and HRs was further used to predict the hold time and total injury time required to attain complete cell destruction at different target PTs and HRs that represents different scenarios of a clinical thermal therapy protocol. Figure $6 \mathrm{a}, \mathrm{b}$ shows the calculated hold time and total time in minutes resulting in complete cell death at target PTs between $60^{\circ} \mathrm{C}$ and $85^{\circ} \mathrm{C}$ and
HRs between 5 and $600^{\circ} \mathrm{C} \mathrm{min}^{-1}$, which represents the transient clinical problem strictly under thermal therapy conditions.

Figure 6a shows that, for a given target PT, the hold time increases with the increase in the HRs. It increases from 0.45 to $8.4 \mathrm{~min}$, from 0 to $2.2 \mathrm{~min}$, from 0 to $0.61 \mathrm{~min}$, from 0 to $0.17 \mathrm{~min}$ and from 0 to $0.05 \mathrm{~min}$ at a target PT of $60,65,70,75$ and $80^{\circ} \mathrm{C}$, respectively. The increase in the hold is negligible at $85^{\circ} \mathrm{C}$. Further, the hold time decreases with the increase in target PT,

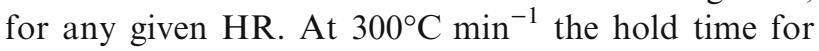
complete cell destruction decreases from $7.2 \mathrm{~min}$ at $60^{\circ} \mathrm{C}$ to $0.4 \mathrm{~min}$ at $80^{\circ} \mathrm{C}$. For very low HRs of 5 and $10^{\circ} \mathrm{C} \mathrm{m^{-1 }}$, complete cell destruction is achieved for target PTs of $65^{\circ} \mathrm{C}$ and above without any hold time.
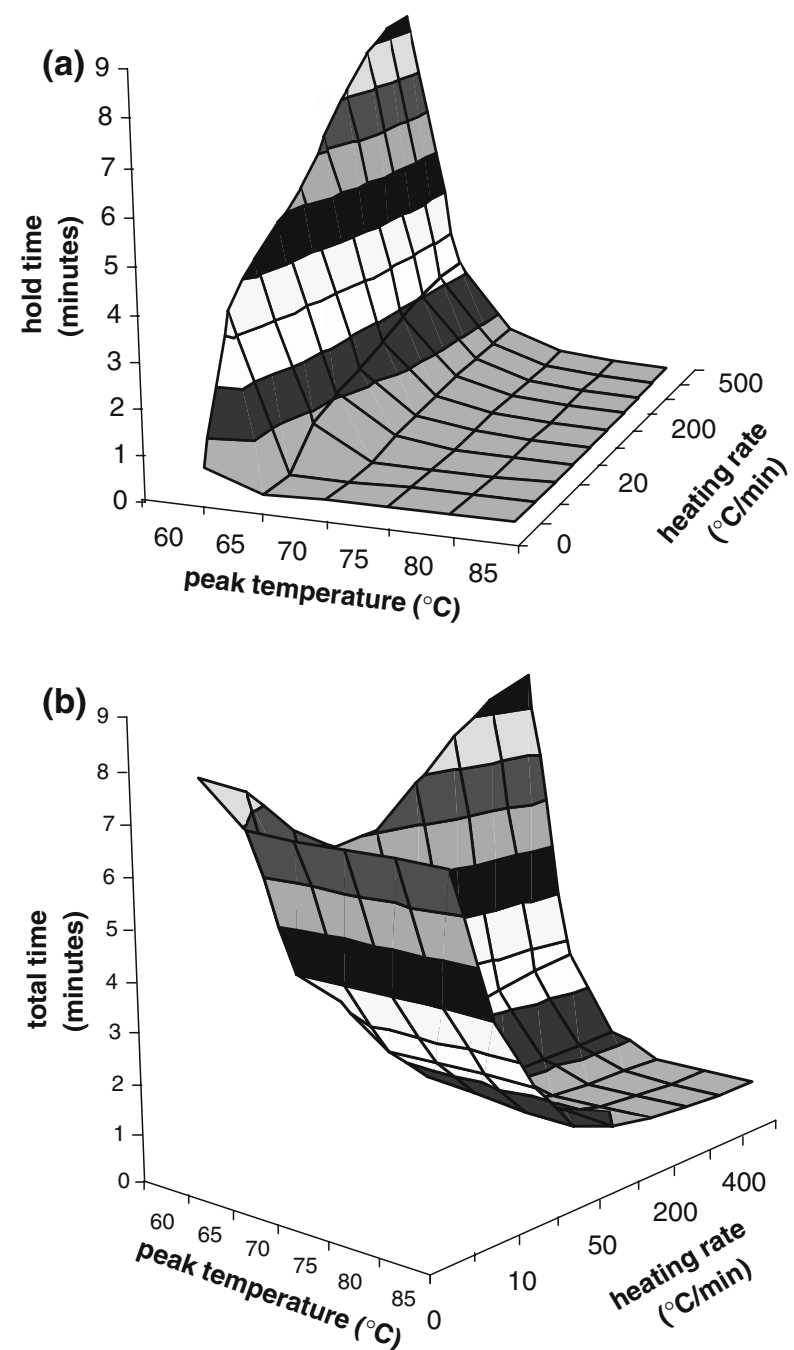

FIGURE 6. (a) Plot of hold time in minutes to attain complete destruction of attached HepG2 cells at various PTs between $50^{\circ} \mathrm{C}$ and $85^{\circ} \mathrm{C}$ and at HRs from 5 to $600^{\circ} \mathrm{C} \mathrm{min}^{-1}$. (b) Plot of total time ( $\mathrm{min})$ to attain complete destruction of attached HepG2 cells at various PTs between $50^{\circ} \mathrm{C}$ and $85^{\circ} \mathrm{C}$ and at $\mathrm{HRs}$ from 5 to $600^{\circ} \mathrm{C} \mathrm{min}^{-1}$. 
Similarly, no hold time is required when the target PTs are $70^{\circ} \mathrm{C}$ and above at $20^{\circ} \mathrm{C} \mathrm{min}^{-1}$ and $75^{\circ} \mathrm{C}$ and above at $50^{\circ} \mathrm{C} \mathrm{min}^{-1}$. Heating, targeted at PTs of $80^{\circ} \mathrm{C}$ and $85^{\circ} \mathrm{C}$, kills all the cells without any hold period for any of the above used HR. These results demonstrate that significant cell death takes place during the ramp up and ramp down period.

Figure $6 \mathrm{~b}$ shows the variation in the total injury time (rise, hold and cooling time) to achieve complete cell destruction with the change in the target PTs and HRs. For 60,65 and $70^{\circ} \mathrm{C}$, the total injury time showed a minima with the decrease in the HR. For example, the total time at the target $\mathrm{PT}$ of $60^{\circ} \mathrm{C}$, decreases from 8.8 for $600^{\circ} \mathrm{C} \mathrm{min}^{-1}$ to 5.9 for $50^{\circ} \mathrm{C} \mathrm{min}^{-1}$ and then again increases to $7.8 \mathrm{~min}$ for $5^{\circ} \mathrm{C} \mathrm{min}{ }^{-1}$. At $65^{\circ} \mathrm{C}$, the total time decreases from $2.7 \mathrm{~min}$ to $2 \mathrm{~min}$ and then increases to $3.2 \mathrm{~min}$ for a decrease of HR from 600 to $100^{\circ} \mathrm{C} \mathrm{min}{ }^{-1}$ and again to $20^{\circ} \mathrm{C} \mathrm{min}^{-1}$, respectively. The trend remains the same at $70^{\circ} \mathrm{C}$, the transition of hold time being at a higher rate of $200^{\circ} \mathrm{C} \mathrm{min}^{-1}$. For target PTs of 75,80 and $85^{\circ} \mathrm{C}$, this trend reverses as the total injury time consistently increases with the decrease in the HR, unlike for all other target PTs. The total time increased almost twice from 0.76, 0.69 and 0.7 at 75,80 and $85^{\circ} \mathrm{C}$ respectively, as the HR dropped from 600 to $50^{\circ} \mathrm{C} \mathrm{min}{ }^{-1}$. For the target PTs $\left(85^{\circ} \mathrm{C}\right.$ to $65^{\circ} \mathrm{C}$ ) where no hold time is required to attain complete cell death, total injury time was obtained as 1 , $1.35,2.4,3.96$ and $6.93 \mathrm{~min}$ at HRs of $100,50,20,10$ and $5^{\circ} \mathrm{C} \mathrm{min}{ }^{-1}$, respectively. The trend in the change of the total injury time with change in target PT, for any given HR remains the same as that for the hold time.

\section{DISCUSSION}

\section{Injury Kinetics of Attached and Suspended Cells}

The comparison of the survival data for the suspended and the attached cells (Fig. 3a, b) indicate that the suspended cells are a slightly more susceptible to heat than the attached ones. He and Bischof ${ }^{15}$ also obtained similar results for SN12 human renal cell carcinoma within the same temperature range, where the reason for this difference between suspended and attached cells was assumed to be the difference in their protein synthesis and gene expression. It may be assumed that some of the above differences also exist between attached and suspended HepG2 cells used in this study. The results shows a clear difference between the frequency factors for both the cell types, but the activation energies does not show much variation. But since the difference in the survival of suspended and attached cells is small either of the cell type can be used in studying the cell injury kinetics in HepG2 cells.

\section{Comparison with Previous Hyperthermic Studies}

Hyperthermic studies are mainly characterized by the presence of a shoulder region followed a slope in the survival curve. In these studies, the shoulder region is typically associated with considerably higher $(\sim 30$ $40 \%$ ) cell survival within a long heating period of few hours and has been observed in the temperature range of $42-45^{\circ} \mathrm{C}$ in many studies. Chinese hamster ovary $(\mathrm{CHO})$ cells showed a small $(15 \%)$ drop in the survival followed by reduction in the slope of the survival curve when heated at $42^{\circ} \mathrm{C}$ for 3 h. ${ }^{9}$ Human melanoma HTB-66 cells, when heated between $42^{\circ} \mathrm{C}$ and $45^{\circ} \mathrm{C}$, also showed a considerably high survival $(\sim 30 \%)$ followed by reduction in the slope at $42.5^{\circ} \mathrm{C}$ even after $5 \mathrm{~h}$ of heating. ${ }^{23}$ In this study, heating at $45^{\circ} \mathrm{C}$ for $15 \mathrm{~min}$ (data not included) and at $50^{\circ} \mathrm{C}$ for 9 min also shows a significantly higher $(>42 \%)$ survival for attached and suspended HepG2 cells indicating the possibility of a shoulder region for these short time protocols. However, whether they biologically behave in a similar fashion to the hyperthermic shoulders by demonstrating thermotolerance has not been studied and further investigation is clearly warranted to verify these facts.

Another important aspect of the single cell heating studies is the presence of a break point, after which the slope of the Arrhenius plot drops significantly with the increasing temperature. The break point is believed to be the indication of an achieved thermotolerance and change in the mechanism/target of the thermally induced cellular injury beyond it. ${ }^{9}$ Such break points have been observed at $43.5^{\circ} \mathrm{C}$ for human cell lines and $43^{\circ} \mathrm{C}$ for rodent cell lines. We have observed no significant break point for our studies between temperatures of $55-70^{\circ} \mathrm{C}$. However, one interesting observation in our study was that heating at $60^{\circ} \mathrm{C}$ for 3 min for attached and suspended cells, shows a sudden change in the slope of the survival curve. The survival drops from $\sim 0.25$ at 2 min to 0.003 after 3 min of heating, suggesting the possibility of a distinct change in the response to heating at $60^{\circ} \mathrm{C}$ for HepG2 cells.

\section{Comparison of Arrhenius Parameters}

This study shows a linear relationship between activation energies and HRs for a temperature range of $50-70^{\circ} \mathrm{C}$. The activation energies between 282.09 $\mathrm{kJ} \mathrm{mol}{ }^{-1}$ and $248.29 \mathrm{~kJ} \mathrm{~mol}^{-1}$ were obtained for HRs of $5-600^{\circ} \mathrm{C} \mathrm{min}-1$, which are within the range of the activation energies obtained in most of the dye uptake assays. Thermal injury in Dunning AT-1 attached prostate cancer cells from $40^{\circ} \mathrm{C}$ to $60^{\circ} \mathrm{C}$ gave activation energy of $245 \mathrm{~kJ} \mathrm{~mol}^{-1}$. Activation energy values obtained in renal cell carcinoma studies are 290$360 \mathrm{~kJ} \mathrm{~mol}^{-1}{ }^{15}$ and in skeletal muscle tissue is 
$230 \mathrm{~kJ} \mathrm{~mol}{ }^{-1} .{ }^{11}$ The activation energies for clonogenic assays for various studies like AT-1 prostate cancer cells $\left(40-70^{\circ} \mathrm{C}\right),{ }^{4} \mathrm{~T} 24$ human bladder carcinoma cells $\left(48-65^{\circ} \mathrm{C}\right)$ and $\mathrm{CHO}\left(48-65^{\circ} \mathrm{C}\right)^{22}$ were found to be 500 , 600 and $680 \mathrm{~kJ} \mathrm{~mol}^{-1}$, respectively. These values are higher than the ones obtained in this study which is not surprising since clonogenic assay yields higher activation energies than dye uptake assays. Since the activation energies obtained in this study are in the same range of the values obtained for other dye uptake assays, we suggest that the mechanism of thermal injury and its measurement is consistent with other studies.

\section{Clinical Relevance}

Clinical thermal therapy is a transient conduction problem as the tumor gets heated by deposition of energy from the source and by diffusion of the heat from the applicator. Based on the size and heat absorption pattern of the tumor, different radial locations are heated to different PTs at different rates. The regions closer to the applicator gets heated to higher PTs at higher HRs than the ones that are further away resulting in different survival patterns at various locations inside the tumor. Thus, accurate prediction of the hold time of the applicator inside the tumor is very important to ensure desired cellular injury accumulation at every location. As in these high temperatureshort time thermal therapy protocols a considerable $(>10 \%)$ injury accumulates within the non-isothermal portion of the thermal history, the determination of the total treatment time (rise, hold and cooling) is also necessary to obtain desired injury accumulation. Since the maximum size of a liver tumor that can be treated using various energy sources is limited to $4-6 \mathrm{~cm}$ diameter, ${ }^{8}$ the HRs between $600^{\circ} \mathrm{C} \mathrm{min}^{-1}$ and $5^{\circ} \mathrm{C} \mathrm{min}^{-1}$ are representative of all the locations within the tumor for any selected energy source, while the temperatures between $85^{\circ} \mathrm{C}$ and $50^{\circ} \mathrm{C}$ are descriptive of the actual temperature distribution inside the tumor during the thermal application. Temperatures higher than $85^{\circ} \mathrm{C}$ might result in carbonization near the applicator as well as overheating of the healthy tissue beyond the edge of the tumor, while temperatures lower than $50^{\circ} \mathrm{C}$ may result in insufficient injury accumulation within the short treatment time. Therefore, design of clinical thermal therapy protocols requires knowledge of the survival patterns for different hold times and precise prediction of hold and total treatment times to obtain desired cellular injury within the above mentioned range of HRs and PTs.

Such an attempt has been made in a previous study carried out by $\mathrm{He}$ and Bischof ${ }^{15}$ on SN12 renal cell carcinoma. The cell injury kinetics, based on the non-isothermal heating at an average rate of $100^{\circ} \mathrm{C} \mathrm{min}^{-1}$, were used to predict the PTs necessary to obtain a considerable ( $>10 \%)$ amount of cellular injury in cells during the rise period. This prediction was extended to various HR-activation energy combinations just by selecting $\mathrm{HRs}$ between $2^{\circ} \mathrm{C} \min ^{-1}$ and $200^{\circ} \mathrm{C} \mathrm{min}^{-1}$ and activation energies up to $1000 \mathrm{~kJ} \mathrm{~mol}^{-1}$. However, experimental calculations to determine $E$ as a function of HRs was not included in above study. The unique feature of this study is that for all PTs, prediction of survival and treatment time at any given HR is based on a specific experimentally calculated $E-A$ combination for that $\mathrm{HR}$, which results in a close approximation of the actual cellular injury for these high temperatures-short time thermal treatments.

An important assumption made in this study is that the HR used to attain a target PT remains constant. The temperature rise on the heating stage, based on the constants $k_{\mathrm{p}}$ and $k_{\mathrm{d}}$ in the feedback loop, was found to be exponential. The HR was approximated by taking a tangent to the temperature-time curve, resulting in a constant value for the entire temperature rise. However, inside a tumor, the bioheat equation is required to model the transient temperature rise which is rarely linear. But as an initial step in understanding the effect of important parameters governing thermal therapy, this assumption may be a good approximation to predict desired cellular injury and Figs. 5 and 6 may provide important insights in this direction.

The predicted survival at different hold times in Fig. 5a-d shows that for any HR, the PT required to attain a considerable amount of injury accumulation ( $>90 \%$ ) decreases as the hold time increases. A smaller flat portion representing complete cell death and the steeper vertical portion representing considerable $(>10 \%)$ survival for zero hold time in Fig. 5a intersects at $70^{\circ} \mathrm{C}$ and complete cell death is observed for HRs of $50^{\circ} \mathrm{C} \mathrm{min}^{-1}$ and lower. This suggests that for HRs of $50^{\circ} \mathrm{C} \mathrm{min}^{-1}$ and lower, typically at the boundary of the tumor, PTs of only $70^{\circ} \mathrm{C}$ and above are capable of accumulating significant amount of injury. This information is helpful in developing treatment protocols for small sized tumors, where the use of high target PTs will not significantly damage the healthy tissue beyond the range of the tumor, even though the temperatures at those locations are higher than $60^{\circ} \mathrm{C}$. As the hold time increases the intersection shifts toward lower PTs increasing the flat portion of complete cell destruction. The decrease in steepness of the vertical portion also implies that sufficient cell damage can be obtained at tumor boundaries at these low temperatures. For example, when the hold time is $5 \mathrm{~min}$, more than $80 \%$ survival is observed even at $55^{\circ} \mathrm{C}$ at the boundary of the tumor where the HR is as 
low as $5^{\circ} \mathrm{C} \mathrm{min}^{-1}$. This shows that thermal protocols with higher hold times are beneficial for cell injury in large size tumors. Since it is necessary that the intersection should coincide with the tumor boundary to maximize the damage within the tumor as well as minimize the damage of the surrounding healthy tissue, the contours obtained in Fig. 5a-d are very important in the selection of the hold times based on the size of the tumor.

Since the goal of every clinical application is complete tumor destruction, it is very important to know the hold time required to destroy all the tumor cells for different PT-HR combinations (that may represent different regions within a tumor depending upon its geometry and the energy source used). Figure 6a shows the hold time necessary to acquire complete damage in attached HepG2 cells at PTs between $60^{\circ} \mathrm{C}$ and $85^{\circ} \mathrm{C}$ and $\mathrm{HRs}$ between $5^{\circ} \mathrm{C} \mathrm{min}^{-1}$ and $600^{\circ} \mathrm{C} \mathrm{min}^{-1}$ and suggests that the hold time increases with the simultaneous decrease in the PT and the HR. Therefore, as the distance from the applicator increases, decreasing the PT and the HR, the hold time for tumor destruction increases. For example, Fig. $6 \mathrm{a}$ shows that the hold time increases from almost zero at $85^{\circ} \mathrm{C}-500^{\circ} \mathrm{C} \mathrm{min}{ }^{-1}$ to $4.84 \mathrm{~min}$ at $60^{\circ} \mathrm{C}-50^{\circ} \mathrm{C} \mathrm{min}{ }^{-1}$. Significant increase in the hold time for PTs of $60^{\circ} \mathrm{C}$ and $65^{\circ} \mathrm{C}$ suggests that in the regions away from the applicator (HRs of $100^{\circ} \mathrm{C} \mathrm{min}^{-1}$ and lower), the injury accumulation strongly depends on the hold time.

However, the hold time is very less for PTs of $70^{\circ} \mathrm{C}$ and above even at high HRs and decreases to almost zero as the HR decreases, suggesting that the majority of the cell damage at these temperatures occurs just within the rise and cooling period. At $70^{\circ} \mathrm{C}$ and above for $\mathrm{HRs}$ of $20^{\circ} \mathrm{C} \mathrm{min}{ }^{-1}$ and lower, the hold time completely vanishes and the thermally induced cellular injury is just a function of the non-isothermal portion of the thermal history. Therefore it is necessary to investigate the variation in the total treatment time (rise, hold and cooling) to attain complete cellular destruction at various PT-HR combinations.

Figure $6 \mathrm{~b}$ shows the variation in the total treatment time based on the temperature distribution within the tumor, depending upon its geometry and the energy source used. For PTs of $75^{\circ} \mathrm{C}$ and above, unlike hold time, the total treatment time increases with the decrease in the HR. This is due to the fact that for HRs above $50^{\circ} \mathrm{C} \mathrm{min}^{-1}$, the hold time is very small and negligible compared to the rise time to reach these high PTs and the time to cool down back to the room temperature. It was also observed that for a given target PT $\left(>70^{\circ} \mathrm{C}\right)-\mathrm{HR}\left(<50^{\circ} \mathrm{C} \mathrm{min}{ }^{-1}\right)$ combination, where the hold time is zero, the total treatment time is lower than the calculated time. This suggests that if damage within a tumor is desired at very slower rate at PTs higher than $70^{\circ} \mathrm{C}$, the tumor actually gets destroyed before even reaching the target PT at any location. But the interesting observation in Fig. 6b is the presence of a minimal total treatment time at PTs of 70,65 and $60^{\circ} \mathrm{C}$ for HRs of 200, 100 and $50^{\circ} \mathrm{C} \mathrm{m^{-1 }}$, respectively. This implies that based on the size of the tumor and the energy source selected, if the temperature distribution within the tumor results in any of the above PT-HR combinations at the boundary, complete cell death can be achieved in the entire tumor within a minimal total treatment time. For example, if the temperature distribution is such that the boundary of the tumor reaches $60^{\circ} \mathrm{C}$ at $50^{\circ} \mathrm{C} \mathrm{min}^{-1}$, the entire tumor can be destroyed in $5.9 \mathrm{~min}$. Thus based on the size of the tumor, Fig. 6a, b may help in selecting hold and total treatment time in order to design an optimal clinical protocol.

Since this study is based on experimental single cell data to obtain the activation energies at different HR, it can serve as an accurate model for designing better thermo-surgical protocols using appropriate energy sources of heat delivery. Also, for a clinician practicing the technique, it can serve as a database, from where an optimal thermal therapy protocol can be selected for the treatment of liver cancer. By selecting appropriate blood flow and tissue properties and by using the bioheat equation, this in vitro protocol can be extended to in vivo clinical protocols.

\section{SUMMARY}

The investigation of injury kinetics in human liver cancer HepG2 cells between temperatures of $50^{\circ} \mathrm{C}$ and $70^{\circ} \mathrm{C}$ at $\mathrm{HRs}$ of $100,200,300$ and $525^{\circ} \mathrm{C} \mathrm{min}{ }^{-1}$ (isothermal) was used to extract Arrhenius parameters, $E$ and $A$, that showed a minor decay with the increase in the HR. The extrapolation of the kinetic parameters over a range of heating conditions showed that the $E$ value decreased from 282.09 to $248.29 \mathrm{~kJ} \mathrm{~mol}^{-1}$ as the HR increases from 5 to $600^{\circ} \mathrm{C} \mathrm{min}^{-1}$. The measured and the predicted survival at all the HRs dropped as the PT and hold time increased. A sharp drop in the survival was observed after $2 \mathrm{~min}$ of heating at $60^{\circ} \mathrm{C}$ for all HRs. The measured and predicted cell survival increased with the increase in the $\mathrm{HR}$ at any PTs and hold time. This increase in the survival reduced significantly for target PTs of $65^{\circ} \mathrm{C}$ and above and for hold times of a minute and higher. The hold time for complete cell damage decreases with the increase in the target PT and increases with the increase in the HR. No hold time is required for target PTs of $75^{\circ} \mathrm{C}$ and above with the decrease in the HR below $100^{\circ} \mathrm{C} \mathrm{min}^{-1}$. The cellular damage is a dominant function of hold time at target PTs of $60^{\circ} \mathrm{C}$ and less 
and for HRs of $50^{\circ} \mathrm{C} \mathrm{min}^{-1}$ and higher. Total time (rise, hold and cooling time) plays a major role in accumulating the cellular injury when the temperatures are $70^{\circ} \mathrm{C}$ and above and when the HRs are between $0^{\circ} \mathrm{C} \mathrm{min}{ }^{-1}$ and $50^{\circ} \mathrm{C} \mathrm{min}^{-1}$. Minimal total treatment time for complete cellular damage was observed at target PTs of 60,65 and $70^{\circ} \mathrm{C}$ and $\mathrm{HRs}$ of 50,50 and $20^{\circ} \mathrm{C} \min ^{-1}$, respectively.

\section{ACKNOWLEDGEMENT}

I would like to thank Dr. Tesfay Meressi, Chairperson, Mechanical Engineering Department, University of Massachusetts, Dartmouth, for help with the feedback control system.

\section{REFERENCES}

${ }^{1}$ American Cancer Society Statistics. Cancer Facts and Figures. American Cancer Society, Inc, Atlanta, GA, USAAmerican Cancer Society Statistics 2004 Cancer Facts and Figures, American Cancer Society, Inc., Atlanta, GA, USA.

${ }^{2}$ Bhowmick, P., S. Bhowmick, J. E. Coad, and J. C. Bischof. In vitro assessment of the efficacy of thermal therapy in human benign prostatic hyperplasia tissue. Int. J. Hyperthermia. 20(4):421-439, 2004.

${ }^{3}$ Bhowmick, S., J. E. Coad, D. J. Swanlund, and J. C. Bischof. In vitro thermal therapy of AT-1 Dunning prostate tumors. Int. J. Hyperthermia. 20(1):73-92, 2004.

${ }^{4}$ Bhowmick, S., D. J. Swanlund, and J. C. Bischof. Supraphysiological thermal injury in dunning AT-1 prostate tumor cells. ASME J. Biomech. Eng. 122:51-59, 2000.

${ }^{5}$ Borrelli, M. J., L. L. Thompson, A. A. Cain, and W. C. Dewey. Time-temperature analysis of cell killing of BHK cells heated at temperatures in the range of 43.5 degree $\mathrm{C}$ to 57 degree C. Int. J. Radiat. Oncol. Biol. Phys. 19(2):389399, 1990.

${ }^{6}$ Bosch, F. X., J. Ribes, and J. Borras. Epidemiology of primary liver cancer. Semin. Liver Dis. 19:271-285, 1999.

${ }^{7}$ Callari, D., G. Blandino, V. Saccone, C. D'Amico, and A. Billitteri. Action of retinol on viable cell recovery and clonogenic potential of HTC cells after in vitro hyperthermia. Boll. Soc. Ital. Biol. Sper. 68(12):783-787, 1992.

${ }^{8}$ Curley, S. Radiofrequency ablation of malignant liver tumors. The Oncologist 6:14-23, 2001.

${ }^{9}$ Dewhirst, M. W., B. L. Viglianti, M. Lora-Michiels, M. Hanson, and P. J. Hoopes. Basic principles of thermal dosimetry and thermal thresholds for tissue damage from hyperthermia. Int. J. Hyperthermia. 19(3):267-294, 2003.

${ }^{10}$ Fong, Y., R. L. Sun, W. Jarnagin, and L. H. Blumgart. An analysis of 412 cases of hepatocellular carcinoma at a Western center. Ann. Surg. 229:790-799, 1999.
${ }^{11}$ Gaylor, D. C. Physical mechanisms of cellular injury in electrical trauma. PhD thesis. Boston, MA: MIT (Lee RC, Supervisor), 1989.

${ }^{12}$ Gilliams, A. R., J. Brokes, and C. Hare. Follow-up of patients with metastatic liver lesions treated with interstitial laser therapy. Br. J. Cancer 76:31.

${ }^{13}$ Hasumura, S., S. Nagamori, K. Fujise, H. Sujino, T. Matsuura, K. Shimizu, and M. Niiya. Effects of TNF on human hepatocellular carcinoma cell lines and their modification by hyperthermia. Human Cell 1(2):238-244, 1988.

${ }^{14} \mathrm{He}, \mathrm{X}$. and J. C. Bischof. Quantification of temperature injury in thermal therapy and cryosurgery. Crit. Rev. Biomed. Eng. 31(5):355-421, 2003.

${ }^{15} \mathrm{He}, \mathrm{X}$. and J. C. Bischof. The kinetics of thermal injury in human renal carcinoma cells. Ann. Biomed. Eng. 33(4):502510,2005

${ }^{16}$ Henriques, F. C. Jr. Studies of thermal injury, the predictability and the significance of thermally induced rate processes leading to irreversible epidermal injury. Arch. Pathol. 43:489-502, 1947.

${ }^{17}$ Itamoto, T., K. Katayama, and S. Fukuda, et al. Percutaneous microwave coagulation therapy for primary or recurrent hepatocellular carcinoma: long-term results. Hepatogastroenterology 48:1401-5, 2001.

${ }^{18}$ Kelvin Kwok-Cha, N. G., et al. Thermal ablative therapy for malignant liver tumors: A critical appraisal. J. Gastroenterol. Hepatol. 18:616-629, 2003.

${ }^{19}$ Landry, J., J. P. Bernier, and N. Marceau. Comparative evaluation of the mammalian cell thermal sensitivity to pulsed CO2-laser irradiation and hyperthermic water-bath treatment. Radiat. Res. 71(1):240-250, 1977.

${ }^{20}$ Muneeb, A. et al. Thermal ablation therapy for HCC. J. Vasc. Interven. Radiol. 13(9 Pt 2):S231-244, 2002.

${ }^{21}$ Pearce, J. and S. Thomsen. Rate process analysis of thermal damage. In Optical Thermal Response of Laser-Irradiated Tissue, edited by A. J. Welch and M. J. C. Van Germert. New York: Plenum Press, 1995.

${ }^{22}$ Prinsze, C., T. M. A. Penning, R. Dubbelman, and J. V. Steveninck. Interaction of photodynamic treatment and either hyperthermia or ionizing radiation and of ionizing radiation and hyperthermia with respect to cell killing of L929 fibroblast, Chinese hamster ovary cells, and T24 human bladder carcinoma cells. Cancer Res. 52:117-120, 1992.

${ }^{23}$ Roizin-Towle, L. and J. P. Pirro. The response of human and rodent cells to hyperthermia. Int. J. Radiat. Oncol. Biol. Phys. 20:751-756, 1991.

${ }^{24}$ Sato, Y., K. Fujiwara, I. Ogata, Y. Ohta, S. Hayashi, Y. Oka, S. Furui, and H. Oka. Transcatheter arterial embolization for hepatocellular carcinoma. Benefits and limitations for unresectable cases with liver cirrhosis evaluated by comparison with other conservative treatments. Cancer 55(12):2822-2825, 1985.

${ }^{25}$ Yamamoto, J., T. Kosuge, and T. Takayama, et al. Recurrence of hepatocellular carcinoma after surgery. $\mathrm{Br}$. J. Surg. 83:1219-1222, 1996. 